\section{Compressive Resistance of Abutments with Different Diameters and Transmucosal Heights in Morse-Taper Implants}

Ricardo Lillo1, Carlos Parra1, Ramón Fuentes², Eduardo Borie², Wilfried Engelke ${ }^{3}$, Victor Beltrán ${ }^{2,3}$

\author{
'Faculty of Dentistry, Universidad \\ Mayor, Santiago, Chile \\ ${ }^{2}$ Dental School, CIMOFIR \\ Research Centre, Universidad de \\ La Frontera, Temuco, Chile \\ ${ }^{3}$ Department of Oral and \\ Maxillofacial Surgery, University \\ of Göttingen, Germany
}

Correspondence: Ricardo Lillo

Espinoza, Américo Vespucio

Sur 357, 7550223 Las Condes,

Santiago, Chile. Tel: +56-600-328-

1000. email: rlilloe@gmail.com

\begin{abstract}
The aim of this study was to evaluate the compressive resistance under oblique loads of abutments with two different diameters and transmucosal heights used for cementretained implant-supported prostheses in Morse-taper implants. Forty Morse-taper implants were divided into four groups with different abutment sizes for cement-retained prostheses in order to perform the compressive test. The groups were divided by abutment diameter and transmucosal height as follows: Group 1: $4.5 \times 2.5 \mathrm{~mm}$; Group 2: $4.5 \mathrm{x}$ $3.5 \mathrm{~mm}$; Group 3: $3.3 \times 2.5 \mathrm{~mm}$; and Group 4: $3.3 \times 3.5 \mathrm{~mm}$. An oblique compressive loading test was performed on each sample located in a platform at $30^{\circ}$ using a universal testing machine with a load cell of $1,000 \mathrm{kgf}$ and $0.5 \mathrm{~mm} / \mathrm{min}$ speed until achieving the deformation of abutment's neck. The compressive resistance and its mechanical behavior were recorded for each group and the data were analyzed using ANOVA, the Shapiro-Wilk and Scheffé tests. In addition, the detailed damage of all samples was recorded with a conventional camera linked to the endoscopic equipment. Significant differences were observed among the groups, except between Groups 2 and 3 ( $p>0.005)$. All the abutments showed permanent deformations in the upper region and at the transmucosal portion, but the threads of the screws were intact. Fractures were only identified in Groups 3 and 4 . Stronger mechanical behavior and compressive resistance was observed in the abutments with $4.5 \mathrm{~mm}$ diameter and $2.5 \mathrm{~mm}$ transmucosal height.
\end{abstract}

Key Words: dental implants, dental implant abutment design, Morse taper, cement-retained prosthesis, compressive resistance.

\section{Introduction}

Despite the high success rate of current dental implant treatments, some mechanical complications may occur, such as abutment loss or implant/abutment fracture (1). Within the current implant connections in the market, the Morse taper connections have shown the highest reliability when subjected to mechanical tests (1). Several studies have been conducted on the stress concentration of different implant/abutment configurations (2-4), but the real clinical significance of these results requires its validation by mechanical tests (1).

The prosthetic treatment involving endosseous implants may include screw-retained or cement-retained restorations (5). The screw-retained implant-supported prostheses were developed to maintain the retrievability and maintenance of the restorations (6). However, the use of cement-retained restorations has increased significantly, mainly because of its esthetic features, passive fit and cost (7), as well as its more favorable stress distribution (4).

The success of cement-retained restorations depends mainly on their retention and adequate resistance (6). In addition, the factors that may influence the success of these types of restorations are the abutment taper, height and width and the cement type (7). Thus, it is important to consider the height and surface area of the abutment choice to replace anterior teeth and posterior teeth (7).

To obtain successful esthetic results, a great variety of abutment sizes for cement-retained implant-supported prostheses are available, which vary in height, diameter and transmucosal height. However, the clinician must consider the indications and mechanical limitations of each abutment's size. Thus, the aim of this study was to evaluate the compressive resistance under oblique loads of abutments with two different diameters and transmucosal heights indicated for cement-retained implant-supported prostheses in Morse-taper implants.

\section{Material and Methods}

Forty Morse-taper implants (Drive Neodent ${ }^{\circledR}$, Curitiba, $P R$, Brazil) were chosen for the study, with a platform of $3.5 \mathrm{~mm}$ diameter and $13 \mathrm{~mm}$ length and a hexahedral prosthetic keying device. All the abutments were $6 \mathrm{~mm}$ high and were screwed over universal implants (CM Exact, Neodent ${ }^{\oplus}$, Curitiba, PR, Brazil). The samples were divided into four groups $(n=10)$ as follows: Group 1: abutment $4.5 \mathrm{~mm}$ diameter and $2.5 \mathrm{~mm}$ transmucosal height; Group 2: abutment $4.5 \mathrm{~mm}$ diameter and $3.5 \mathrm{~mm}$ transmucosal height; Group 3: abutment $3.3 \mathrm{~mm}$ diameter and $2.5 \mathrm{~mm}$ 
transmucosal height; Group 4: abutment $3.3 \mathrm{~mm}$ diameter and $3.5 \mathrm{~mm}$ transmucosal height.

Each Morse-taper implant was placed in a polyamide cylinder (Technyl, Rhodia, São Bernardo do Campo, SP, Brazil) maintaining a flat top surface between the implants and the cylinder (Fig. 1A). Subsequently, all the abutments were installed into the implants with $15 \mathrm{~N} . \mathrm{cm}$ torque measured with a digital torque meter as recommended by the manufacturer. Then, an oblique compressive loading test was performed on each sample by a universal testing machine (Instrom, Boston, MA, USA). The implants were located on a platform at a $30^{\circ}$ angle (Fig. 1B), and a load cell of $1000 \mathrm{kgf}$ at $0.5 \mathrm{~mm} / \mathrm{min}$ speed was applied at the center of the abutment top until plastic deformation of the abutment neck was achieved. The universal testing machine was programmed to stop the load $1 \mathrm{~mm}$ after beginning of plastic deformation of the transmucosal portion. The values of compressive resistance were recorded. Furthermore, the detailed damage of all the samples was recorded with a conventional camera linked to endoscopic equipment Storz 487 B and a Xenon 300 W light with $6000 \mathrm{~K}$ capacity, which mainly consisted of a rigid $2.7 \mathrm{~mm}$ endoscope (Karl Storz, Tuttlingen, Germany). The images were then compared between them.

Data were analyzed by ANOVA to determine if there were significant differences between the groups and the Scheffé test was used to analyze the groups that showed the differences. All analyses were performed by the Systat software (v. 11.0, Systat Software Inc., San Jose, CA, USA) with a significance level of $5 \%$.

\section{Results}

The means and standard deviations of maximum compressive load for each group are summarized in Table 1. The statistical analysis exhibited significant differences among the groups, except between Groups 2 and 3 ( $p>0.005$ ). In addition, all the abutments showed permanent deformations in the upper region and at the transmucosal portion, but the threads of the screw and the abutmentimplant junction were intact (Fig. 2).
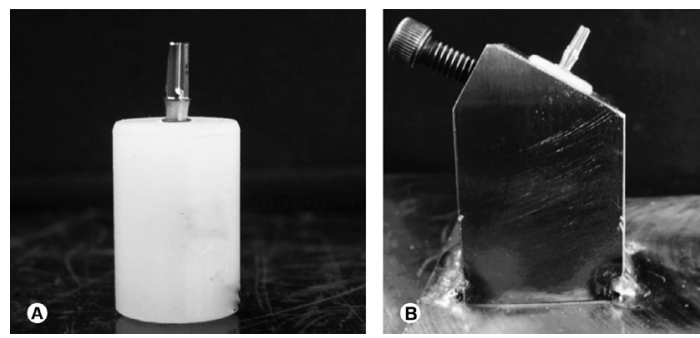

Figure 1. A: Implant placed at polyamide cylinder. B: Sample positioned on a $30^{\circ}$ angle platform to be submitted to mechanical test.
It was observed that a lower transmucosal height resulted in a greater magnitude of the peak load for each sample. In contrast, a direct correlation between the abutment diameter and maximum compressive load was also noted, i.e., a larger diameter resulted in a greater compressive resistance.

No fractures were observed in Groups 1 and 2 (Fig. 3A). In contrast, fractures were observed in the coronal portion of the abutment in Groups 3 and 4 (Figs. 3B and 3C). The mechanical behaviors of Groups 1 and 2 and Groups 3 and 4 under compressive load are summarized in Figures 4 and 5 , respectively.

\section{Discussion}

With the positive learning curve in implant dentistry in the last decade, the survival rate for cemented implantsupported prostheses increased to over $97 \%$ (8). However, it is important to note that the foresight and long-term success of an implant are greatly influenced by the biomechanical environment to which it is exposed (3).

Fractures were only observed in the coronal portion of the $3.3 \mathrm{~mm}$ diameter abutments. In addition, the damage was only observed at the coronal portion as well as the transmucosal portion of abutments, without identifying any alteration at the implant neither the abutment's screw threads. These results concur with those reported by Coppedê et al. (9) regarding the observation of a permanent deformation in the platform and neck of the abutments, but these authors did not identify any abutment fracture.

The transmucosal height affects the compressive resistance with a higher resistance at $2.5 \mathrm{~mm}$. This finding may be explained by the lower height of the transmucosal portion, creating a lower lever arm when compared with the abutment with a $3.5 \mathrm{~mm}$ transmucosal height, on which the fulcrum is located at the neck surface of the abutment. Furthermore, the $4.5 \mathrm{~mm}$ diameter abutment demonstrated the highest compressive resistance, possibly because of its higher amount of titanium.

No fractures of the abutment's screws or abutment loosening were observed in all groups, probably because

Table 1. Mean $(\mathrm{N})$ and standard deviation (SD) of maximum deformation load (N) for each group

\begin{tabular}{lcccc}
\hline Groups & Minimum (N) & Maximum (N) & Mean (N) & S.D. \\
\hline 1 & 600.6 & 608.7 & 605.7 & \pm 2.33 \\
2 & 530.8 & 542.4 & 536.5 & \pm 3.63 \\
3 & 503.9 & 517.9 & 511.6 & \pm 4.78 \\
4 & 440.2 & 464.1 & 449.0 & \pm 6.52 \\
\hline
\end{tabular}


of the Morse taper biomechanics, which is based on the frictional retention of the implant-abutment system (10), its deepest implant connection, in addition to the conical interface that resists lateral loads (11) thereby opposing bending movements $(12,13)$. Morse-taper implants act as single body (14), which scatter the forces through the whole lateral walls (15) and reduce the strain on the fixation screw of the abutment when loaded (10).

The deformation of the transmucosal portion in all groups could be explained by the compressive oblique load applied between the transmucosal portion and the implant neck, leading to great stress concentration and producing a high bending moment. Thus, a higher stress concentration may be observed in the junction between the implant internal neck region and the abutment without damage of the implant threads in Morse-taper implants as demonstrated the finite element studies of some authors $(3,16)$.

It must be noted that in the $4.5 \mathrm{~mm}$ abutment diameter, the abutment deformation was produced simultaneously in the coronal and transmucosal portions, which is in contrast to $3.3 \mathrm{~mm}$ diameter abutments, in which the coronal part exhibits the deformation first, followed by the transmucosal portion.

Considering that the incisors region present maximum bite force ranging between the 150-180 N mean (17-19), all the abutments used in this study could be used clinically without undergoing deformation. However, at the molar
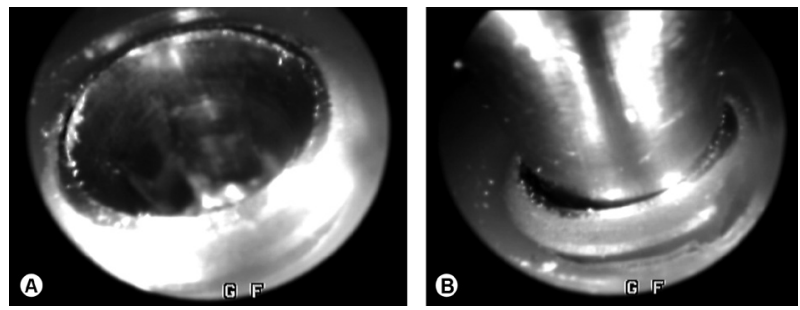

Figure 2. Endoscopic view to check possible fractures. A: Implant neck without the abutment. B: Implant-abutment junction.

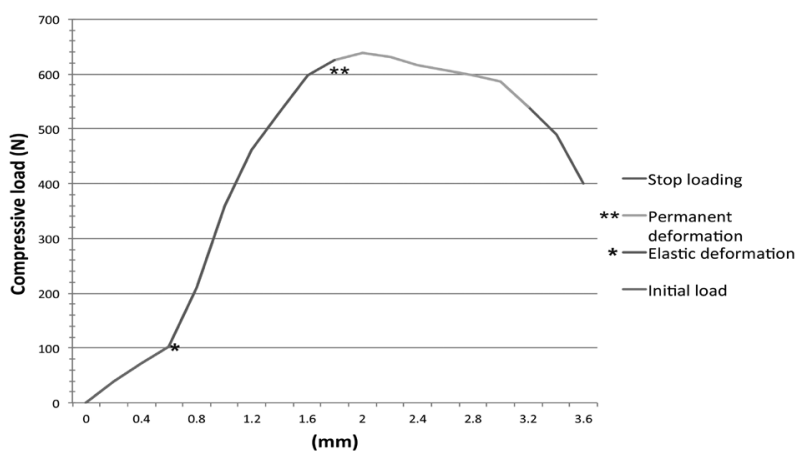

Figure 4. Summary of mechanical behavior of Groups 1 and 2. region, the maximum bite force reported in the literature varies between 505-580 N (19-21). In addition, Al-Omiri et al. (22) described a mean of $577.9 \mathrm{~N}$ for maximum bite force in implant-supported prostheses. Moris et al. (23) declared that the abutment deformation would not occur clinically under normal masticatory forces, mainly because of the protective forces of the crown over the abutment. The authors suggest the use of $4.5 \mathrm{~mm}$ diameter abutments in the molar region to avoid a possible mechanical complication.

It is important to note that this study has some limitations such as the single angle of load application ( $\left.30^{\circ}\right)$ and the absence of a crown restoration. In addition, the load used in all models was a mean found in the literature and does not necessarily represent the occlusal load in all patients. It must be considered that the load conditions in vivo are more complex because of the various forces and moments developing in different locations of the

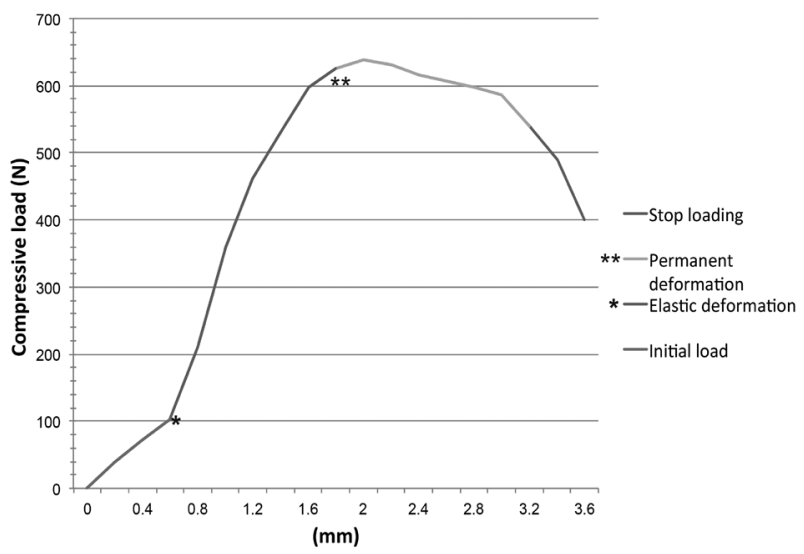

Figure 3. A: Coronal fracture of abutment of $3.3 \mathrm{~mm}$ in diameter. B: Deformation of abutment of $4.5 \mathrm{~mm}$ in diameter over the platform. C: Note the transmucosal deformation.

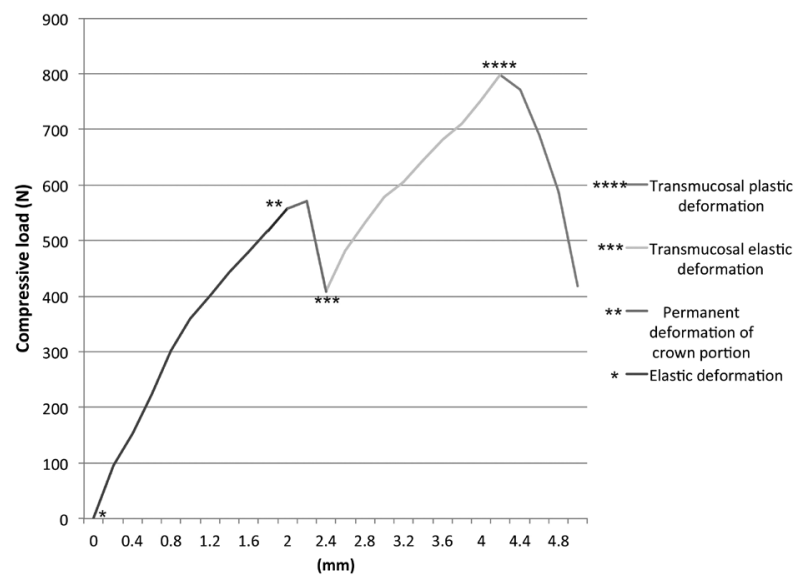

Figure 5. Summary of the mechanical behavior of Groups 3 and 4. 
prosthesis (24).

The results of this research suggest that $4.5 \mathrm{~mm}$ abutments could be used both in the incisor and the molar regions because of their mechanical resistance. In contrast, it can be recommended using $3.3 \mathrm{~mm}$ abutments only in the incisor region. Nevertheless, further studies with a larger abutment features, dynamic loads, thermocycling and different angles of oblique loads could lead to a better interpretation of these preliminary results.

The abutment's diameter seems to influence the mechanical behavior related to permanent deformation, providing a higher compressive resistance in $4.5 \mathrm{~mm}$ diameter abutments. In addition, abutments with a transmucosal height of $2.5 \mathrm{~mm}$ showed a significantly greater compressive resistance than abutments $3.5 \mathrm{~mm}$ high.

\section{Resumo}

0 objetivo deste estudo foi avaliar a resistência compressiva sob carga oblíqua em pilares com dois diferentes diâmetros e alturas de transmucoso usados para prótese implanto-suportada cimentada em implantes de cone Morse. Quarenta implantes de cone morse foram divididos em quatro grupos com diferentes tamanhos de pilares para próteses cimentadas a fim de realizar o teste compressivo. Os grupos foram divididos pelo diâmetro do pilar e altura de transmucoso como segue: 1) $4,5 \times 2,5 \mathrm{~mm}$; 2) $4,5 \times$ $3,5 \mathrm{~mm}$; 3) $3,3 \times 2,5 \mathrm{~mm}$; e 4) $3,3 \times 3,5 \mathrm{~mm}$. Um ensaio de compressão oblíqua foi realizado em cada amostra localizada numa plataforma a $30^{\circ}$ utilizando uma máquina de ensaios universal, com célula de carga de 1.000 $\mathrm{kgf} \mathrm{e} 0,5 \mathrm{~mm} / \mathrm{min}$ de velocidade até atingir a deformação do pescoço do pilar. A resistência compressiva e seu comportamento mecânico foram registrados para cada grupo e os dados foram analisados utilizando os testes Shapiro-Wilk, ANOVA e Scheffé. Além disso, a deformação detalhada de todas as amostras foi registrada com uma câmera convencional conectada ao equipamento endoscópico. Foram observadas diferenças significativas entre os grupos, com exceção dos Grupos 2 e $3(p>0,005)$. Todos os pilares mostraram deformação permanente na região superior $e$ na porção transmucosa; porém, as roscas dos parafusos estavam intactas. Fraturas foram apenas identificadas nos Grupos 3 e 4. Foi observado melhor comportamento mecânico e resistência compressiva nos pilares com diâmetro de $4,5 \mathrm{~mm}$ e altura de transmucoso de $2,5 \mathrm{~mm}$.

\section{Acknowledgements}

The authors want to acknowledge Neodent Implante Osteointegrável (Curitiba, PR, Brazil) for providing the implants and prosthetic components.

\section{References}

1. Almeida EO, Freitas AC Jr., Bonfante EA, Marotta L, Silva NR, Coelho PG. Mechanical testing of implant-supported anterior crowns with different implant/abutment connections. Int J Oral Maxillofac Implants 2013;28:103-108.

2. Baggi L, Cappelloni I, Di Girolamo M, Maceri F, Vairo G. The influence of implant diameter and length on stress distribution of osseointegrated implants related to crestal bone geometry: a three-dimensional finite element analysis. J Prosthet Dent 2008;100:422-431.

3. Pessoa RS, Muraru L, Junior EM, Vaz LG, Sloten JV, Duyck J, et al.. Influence of implant connection type on the biomechanical environment of immediately placed implants - CT-based nonlinear, three-dimensional finite element analysis. Clin Implant Dent Relat Res 2010;12:219-234.

4. Tonella BP, Pellizzer EP, Ferraco R, Falcon-Antenucci RM, Carvalho PS,
Goiato MC. Photoelastic analysis of cemented or screwed implantsupported prostheses with different prosthetic connections. J Oral Implantol 2011;37:401-410.

5. Vigolo P, Mutinelli S, Givani A, Stellini E. Cemented versus screwretained implant-supported single-tooth crowns: a 10-year randomised controlled trial. Eur J Oral Implantol 2012;5:355-364.

6. Saleh Saber F, Abolfazli N, Nuroloyuni S, Khodabakhsh S, Bahrami $M$, Nahidi $R$, et al. Effect of abutment height on retention of single cement-retained, wide- and narrow-platform implant-supported restorations. J Dent Res Dent Clin Dent Prospects 2012;6:98-102.

7. Hebel KS, Gajjar RC. Cement-retained versus screw-retained implant restorations: achieving optimal occlusion and esthetics in implant dentistry. J Prosthet Dent 1997;77:28-35.

8. Pjetursson BE, Asgeirsson AG, Zwahlen $M$, Sailer I. Improvements in implant dentistry over the last decade: comparison of survival and complication rates in older and newer publications. Int J Oral Maxillofac Implants 2014;29 Suppl:308-324.

9. Coppedê AR, Bersani E, Mattos MG, Rodrigues RC, Sartori IA, Ribeiro RF. Fracture resistance of the implant-abutment connection in implants with internal hex and internal conical connections under oblique compressive loading: an in vitro study. Int J Prosthodont 2009;22:283286.

10. Weigl P. New prosthetic restorative features of Ankylos implant system. J Oral Implantol 2004;30:178-188.

11. Merz BR, Hunenbart $S$, Belser UC. Mechanics of the implant-abutment connection: an 8-degree taper compared to a butt joint connection. Int J Oral Maxillofac Implants 2000;15:519-526.

12. Norton MR. An in vitro evaluation of the strength of an internal conical interface compared to a butt joint interface in implant design. Clin Oral Implants Res 1997:8:290-298.

13. Norton MR. Assessment of cold welding properties of the internal conical interface of two commercially available implant systems. J Prosthet Dent 1999;81:159-166.

14. Akça K, Cehreli MC. A photoelastic and strain-gauge analysis of interface force transmission of internal-cone implants. Int J Periodontics Restorative Dent 2008;28:391-399.

15. Maeda $Y$, Satoh T, Sogo M. In vitro differences of stress concentrations for internal and external hex implant-abutment connections: a short communication. J Oral Rehabil 2006;33:75-78.

16. Tang CB, Liul SY, Zhou GX, Yu JH, Zhang GD, Bao YD, et al. Nonlinear finite element analysis of three implant-abutment interface designs. Int J Oral Sci 2012;4:101-108.

17. Garner LD, Kotwal NS. Correlation study of incisive biting forces with age, sex, and anterior occlusion. J Dent Res 1973;52:698-702.

18. Helkimo $E$, Carlsson GE, Helkimo M. Bite force and state of dentition. Acta Odontol Scand 1977;35:297-303.

19. Regalo SC, Santos CM, Vitti M, Regalo CA, Vasconcelos PB, Mestriner $W$, et al.. Evaluation of molar and incisor bite force in indigenous compared with white population in Brazil. Arch Oral Biol 2008;53:282286.

20. Bakke M, Michler L, Han K, Moller E. Clinical significance of isometric bite force versus electrical activity in temporal and masseter muscles. Scand J Dent Res 1989;97:539-551.

21. Varga S, Spalj S, Lapter Varga M, Anic Milosevic S, Mestrovic S, Slaj M. Maximum voluntary molar bite force in subjects with normal occlusion. Eur J Orthod 2011;33:427-433.

22. Al-Omiri MK, Sghaireen MG, Alhijawi MM, Alzoubi IA, Lynch CD, Lynch E. Maximum bite force following unilateral implant-supported prosthetic treatment: within-subject comparison to opposite dentate side. J Oral Rehabil 2014;41:624-629.

23. Moris IC, Faria AC, Mattos MG, Ribeiro RF, Rodrigues RC. Mechanical analysis of conventional and small diameter conical implant abutments. J Adv Prosthodont 2012;4:158-161.

24. Brunski JB. Biomechanical factors affecting the bone-dental implant interface. Clin Mater 1992;10:153-201. 